\title{
Modeling the Role of Government, Firm, and Civil Society for Environmental Sustainability
}

\author{
Humaira Yasmeen, Nanjing University of Aeronautics and Astronautics, Nanjing, China \\ Ying Wang, Nanjing University of Aeronautics and Astronautics, Nanjing, China \\ Hashim Zameer, Nanjing University of Aeronautics and Astronautics, Nanjing, China \\ Hina Ismail, NUML Multan Campus, Multan, Pakistan
}

\begin{abstract}
The objective of this article is to design a game theory-based model to outline the role of the government, firm and civil society for environmental sustainability. The study used the dynamic game theory of complete information. Based upon the equilibrium analysis, the study highlights that when the punishment for non-compliance with environmental responsibility is smaller, the role of civil society would be higher for environmental sustainability. On the other hand, when the environmental responsibility cost is higher, then the role of a government is also higher for the implementation of environmental responsibility and to ensure the punishment. However, the authors found from model analysis that if the cost is low, the probability of firm to fulfill environmental responsibility is higher. In real life, the high cost of environmental responsibility is the main reason that the firm does not fulfill environmental responsibility. Under the high cost, the firm often has the phenomenon of bribery to the government and other means to avoid environmental responsibility. This article is a valuable policy guide for policy makers to cope with global environmental challenges.
\end{abstract}

\section{KEYWORDS}

Cost, Environment, Game Theory, Pakistan, Sustainability

\section{INTRODUCTION}

Creating sustainable futures, countries need to emphasize on multiple initiatives including the reduction in greenhouse gas emissions, protecting a natural environment and focusing on human development (Sassi, 2016). Energy production and environmental issues have to be considered within the context of socio economic sustainability that enables and provides support for positive development of countries, communities and individuals (Epstein \& Buhovac, 2014; Roseland, 2000). In the whole scenario of environmental sustainability, the communities have a main role. However, communities cannot be forced to adopt environmental friendly life style. But, they need to be offered an environmentally viable alternative to their current lifestyle. The goal of environmental sustainability cannot be achieved without simultaneously considering the quality of life.

Globally, in the context of developing countries, the living standards are very low as compare to developed countries (Poudel, 2016). However, in the context of developing country it is difficult to manage the environmental sustainability along with the quality of life. Currently, developing countries 
are facing environmental challenges due to an imbalance in the economic and social development of recent years (Qureshi, 2010). The major cities face haphazard, unplanned expansion due to the shift of the rural population toward urban areas that has worsen the situation (Waseem et al., 2014). The municipal authorities in developing countries also have limited resources; the haphazard urbanization is the core reason of deterioration of natural resources (Qureshi, 2010). Moreover, Pakistan a developing country is facing a severe energy shortage since last two decades similar to other developing countries of the world (Khalil \& Zaidi, 2014; Valasai et al., 2017; Zameer \& Wang, 2018). Presently, to overcome an energy shortage, the government has taken initiatives to install coalbased power plants (Massarrat Abid \& Ashfaq, 2015; Edenhofer, Steckel, Jakob, \& Bertram, 2018). On one end coal-based power plants will help to overcome the energy shortage in the country. On the other hand, it is harmful to the environment (Coutinho \& Butt, 2014). At a time when developed nations are shifting their energy sources from coal to renewable and environmental friendly energy production, the initiative of Pakistani government to install coal power plants in the country is strange enough. No doubt, energy is an essential element for the quality of life and economic development. However, it's the responsibility of the government to ensure the availability of cheap, reliable and environmental friendly energy in the country.

Furthermore, the industrial sector is one of the growing sectors worldwide. As a result of industrial sector growth, environmental issues have evolved world-wide (Eliana Andréa Severo, de Guimarães, Dorion, \& Nodari, 2015). However, in that perspective, the environmental degradation in any country can harm the overall ecosystem, and its negative impacts can also be felt in neighboring countries (Rosenbloom, 2001; Eliana Andrea Severo, de Guimarães, \& Dorion, 2017). The study of (Eliana Andréa Severo \& Guimarães, 2015) indicated that a large number of firms have consensus that environmental sustainability can be a strategic part of organizational development and are designing business models to incorporate environmental problems and embracing competitive advantages. Similarly, the firms operating in the developing countries can reduce their environmental effect by using an environmental friendly production system. Qudrat-Ullah and Karakul (2007) suggested that new policy incentives should be introduced to cope with environmental issues. Such as, to cope with environmental issues, industrialized nations have signed a second commitment (Doha Amendment to the Kyoto Protocol) in 2012 to reduce national $\mathrm{CO}_{2}$ by $18 \%$ during year 2013-2020.

Even though, environmental policies are designed and negotiated in the parliament of democratic countries, but ultimately policy makers need to get support from the domestic public in order to implement policies in effective manners (Bernauer \& Gampfer, 2013; Zürn, 2004). However, to make environmental policies effective and acceptable, scientific literature advocates that the government should engage civil society in environmental policy development (Bernauer, Gampfer, Meng, \& Su, 2016; Betsill \& Corell, 2008; Yamin, 2001). The involvement of civil society can improve the transparency of policy options and bargaining positions (Grigorescu, 2007). And it also, enables citizens to get more information about policy reforms that help them to assess whether their representatives are working in accordance with local interests, and to hold them accountable (Drews \& Van den Bergh, 2016). Moreover, civil society can influence the government actors to ensure the transparency and publicize the relevant information (Van Rooy, 2004). Based upon subsequent discussion, we can argue that the government, firm and civil society have a crucial role for environmental sustainability. But, no study in the past has addressed the phenomena that when, how and to what extent the government, firm and civil society should play their role to ensure sustainable environment for the nations.

Therefore, to address theoretical shortcomings, the purpose of this study is to design a new game theory-based model to outline the role of a government, firm and civil society to cope with environmental issues worldwide. This study used the dynamic game theory of complete information to understand the equilibrium solutions for the government, firm and civil society. First time, this study provides the basis for policy makers to understand how and when the government, firm and civil society must intervene and play a vital role for environmental sustainability. 


\section{LITERATURE REVIEW}

Environmental issues and pollution are considered as extremely dangerous hazards worldwide. Natural problems are approaching highly risky points, because people are unaware of their insecurity. Today, countries are emphasizing to cope with the elements those are creating environmental issues and making lives difficult for individuals. There are many ecological issues in developing countries, however, to address the ecological issues no serious effort has been made. Moreover, many environmental issues are inherent in developing countries, which are of great concern for its sustainable economic future. These environmental issues include water pollution (Azizullah, Khattak, Richter, \& Häder, 2011), air pollution (Ali \& Athar, 2008), noise pollution (Mehdi, Kim, Seong, \& Arsalan, 2011), deforestation (Ahmed, Shahbaz, Qasim, \& Long, 2015), pesticide misuse (Tariq, Afzal, Hussain, \& Sultana, 2007), natural disasters (Finch et al., 2016), climate change (Khan, Khan, Ali, Ahmad, \& Ahmad, 2016), urbanization (Azam \& Khan, 2016), desertification (Zhang, Andam, $\&$ Shi, 2017) and energy production (Coutinho \& Butt, 2014; Qudrat-Ullah, 2015).

The main contributor to the intensity of environmental issues is the industrial sector development along with population growth (Önder \& Akay, 2015). According to World Factbook (CIA) Pakistan a developing country is $7^{\text {th }}$ populous country in the world with a population more than 200 Million. The population in all other developing countries is growing at a fastest rate and according to estimates it will become double in 25 years. If the population in the developing continues to grow at this rate, it will create worse conditions for the environment. Unfortunately, the developing countries don't have enormous resources to sustain such a huge population. Moreover, to fulfill employment and other requirements of the people, the industrial sectors are continuously growing in these countries. Currently, the industrial sector contributes more than 20\% in total GDP. The industrial sector in mostly developing countries is majorly consisting of food processing, chemical, agriculture and other industries. Due to these industries, climate change issues are extremely sensitive in the context of developing countries like Pakistan. According to the study of Muhammad Abid, Schilling, Scheffran, and Zulfiqar (2016), Pakistan is highly vulnerable to climate change. Climate change forecasts have anticipated severe and more frequent droughts which may lead to the major loss of trees and subsequent deforestation (March, 2016).

Furthermore, water is an essential element for human survival. The freshwater encompasses $3 \%$ of total water on the earth. However, a very small percentage $(0.01 \%)$ of freshwater is available for human usage. Unfortunately, this small percentage of fresh water is under immense stress due to urbanization and unsustainable water consumption in industry and agriculture (Azizullah et al., 2011). Moreover, industrial disposal creates worse conditions for the availability of fresh water (Daud et al., 2017). Environmental pollution becomes more severe due to urbanization, population growth and industrialization (Önder \& Akay, 2015). Similarly, population growth and urbanization increases the traffic flow in the big cities that creates noise pollution. The study of Fiedler and Zannin (2015) suggested that to control the noise pollution, the traffic flow should be minimized. However, it is difficult to control the traffic flow because most of the industries are situated in big cities. The smooth movements of labor, raw material and finished goods from industries need a high traffic flow that increases noise pollution in big cities. Moreover, the misuses of pesticides are also creating severe environmental problems in developing countries. For example, as the study has shown that the ground water in Punjab and Sindh (Pakistan) has been found contaminated due to the huge use of pesticides (Tariq et al., 2007). To cope with the environmental pollution coming from factories, the government needs to design a cooperative compliance with factories. Further, the government should also engage civil society to cooperate with the government to control the urbanization and misuse of pesticides in developing countries.

In addition, energy production is highly skewed towered thermal sources (Wakeel, Chen, \& Jahangir, 2016; Zameer \& Wang, 2018). According to scientific literature, the energy production from thermal sources create worse conditions for the environment (Anwar, 2016; Zaman, Abdullah, \& Ali, 
2017). However, it is the responsibility of the government to ensure environmental friendly energy production. The study of (Zaman et al., 2016) has suggested the for environmental sustainability, renewable energy is a better alternative of energy production. For instance, the current energy production mix of the China, India and Pakistan are creating severe conditions for the environment in South Asia. Past studies have indicated that more than $32 \%$ of $\mathrm{CO}_{2}$ and $42 \% \mathrm{SO}_{2}$ emissions are emitting from the energy sector (Anwar, 2016; Harijan, Uqaili, Memon, \& Mirza, 2011; Zaman et al., 2017). Therefore, it can be argued that the governments should emphasize on energy production from renewable energy sources to safeguard the environment in the country. As studies of (Farooqui, 2014; Sheikh, 2009; Zameer \& Wang, 2018) has highlighted that Pakistan has 1100 kilometers (km) a coastal line having huge potential of wind energy production, but the country is producing a small part of energy from the wind. Wind energy considerably decreases dependency on fossil fuels, which strengthen global energy security. And also wind energy doesn't emit dangerous gases also it doesn't contribute to global climate change or global warming. Therefore, the governments in developing countries should play their role for environmental sustainability and shift energy production from current sources to renewable energy.

Summing up the aforesaid discussion, it can be argued that the government and factories both are responsible for continuous damage to the environment. However, the common man is being affected at large by environmental issues. Thus, authors believe it is highly significant that the government, firm and civil society should play their role to cope with environmental issues. But, when, how and to what extent each participant should intervene and play a vital role for environmental sustainability, need to be answered. Therefore, designing a model to outline the role or each participant is extremely important.

Designing a model to address environmental issues, game theory provides a good theoretical basis for modeling to understand and encounter environmental issues. As the study of ( $\mathrm{Li} \& \mathrm{Xu}$, 2018) used game theory for pollution governance in china and studied the role of local government, central government and firms. Shi, Wang, Fu, and Xue (2017) applied game theory to cope with environmental challenges and found that best way is to long-term cooperation which can help to sustain environment. Gao et al. (2018) applied game theory for environmental risk mitigation. Therefore, we believe game theory is best fit to be used to outline the role of the government, firm and civil society for environmental sustainability. In a real world, the strategy of one player can significantly influence the actions of other players. As the study of (McVea \& Charalambu, 2014), argued that participants in any scenario are convinced to act strategically. Similarly, in the case of environmental sustainability, the decisions of the government can significantly influence the actions of firms operating in the country. Also, the role of civil society can significantly influence the decisions of the government and firms. The study of (Cheffins, 1997) stated that a game is a situation in which actions of players can significantly influence the utility of others. Similarly, green regulations introduced by the government can significantly influence the profitability of the firms and also the benefits of society. According to (Schelling, 2010) game theory helps explore and understand the situation in which players, make interdependent decisions which can be defined as strategic interactions. Colman (2013) argued that game theory is that there are two or more players (decision makers) involved, each of them have a choice to act according to best of his/her knowledge to maximize its utility. In this paper, authors analyzed the available options for the government, firm and civil society to cope with environmental challenges worldwide. Initially, game theory was developed by John von Neumann (Poundstone, 1993). Myerson (2013) stated that game theory can be divided into two distinguish types i.e. static and dynamic games. In a static game all players make decisions simultaneously, however in a dynamic game sequential moves are performed. The famous game of the prisoner dilemma is categorized as a static game. However, the chess game is an example of a dynamic game (Zameer, Wang, Yasmeen, Mofrad, \& Saeed, 2018). It can be stated that information are known to all participants, the game is categorized as a game of complete information. Conversely, when all participants don't have equal information, the game is categorized as a game of incomplete information. In the context of 
environmental sustainability, the government and civil society knows about the firms operating in the country. Firms also know the rules and regulations of the country. So, it can be argued that all the players i.e. the government, firm and civil society have equal information. Therefore, this kind of situation can be categorized as the game of complete information. Further, the decisions of firm and civil society are dependent upon the rules and regulations introduced by the government. Therefore, this kind situation in which firm and civil society act based upon the initiatives of the government and all participants i.e. the government, firm and civil society have equal information, the case is considered as dynamic game of complete information. Thus, the study used dynamic game of complete information to classify the role of the government, firm and civil society to address environmental issues worldwide. Moreover, the solution concept used in game theory is called Nash-equilibrium. The concept was named as Nash-equilibrium after mathematician, John Forbes Nash Jr. who introduced this solution concept (Osborne \& Rubinstein, 1994). Nash equilibrium is a fundamental concept in game theory, and it is widely used in predicting the outcomes of strategic interactions in the social sciences.

\section{MODEL AND METHODOLOGY}

The study used a dynamic game theory of complete information for the assessment of environmental responsibility. Based upon the proceeding discussion, the study designed a game theoretic model to address the environmental issues. The scientific literature and common knowledge suggests that the government and industries are liable for environmental issues worldwide. However, the common man is most affected by environmental problems around the globe. In the context of this study, it is presumed that the information's are fully known to the government, firm and civil society. Therefore, in the context of complete information, scientific literature suggests that a dynamic game of complete information provides good theoretical basis to reach at an equilibrium situation (Bajari, Hong, \& Ryan, 2010; Rasmusen \& Blackwell, 1994; Wolters \& Schuller, 1997). In order to achieve the objectives of the study, there is a need to first conceptualize the role of the government, firm and civil society in game analysis.

\section{Three Players Dynamic Game Model}

In this study, it is assumed that all three players those have concern related to environmental issues i.e. the government, firm and civil society are rational participants.

\section{Assumptions and Parameters}

1. The firm fulfills its responsibility for the purpose of sustainable environment, the cost of environmental sustainability is C, and in a case the firm doesn't fulfill its environmental responsibility then a firm need to pay a fine to the government with the amount of EC. However, under the normal situation, specifically in the context of developing countries, the fine imposed by the government is lower as compare to the cost of environmental responsibility. So, firms prefer to not satisfy its environmental responsibility and earn (1-E)C where $\mathrm{E}$ is coefficient and can be $0<\mathrm{E}<1$.

2. The government is responsible for the supervision upon the firms operating in the country and if the government accepts bribes it will face the MC penalty imposed by global organizations; firm shall also be penalized by $\mathrm{U}(1-\mathrm{E}) \mathrm{C}$. The penalty on the government may be imposed by the Kyoto convention that enforces governments to play their role for the purpose of environmental sustainability. When the government doesn't play the role for environmental sustainability it may face the restrictions on exports. Further, if the government doesn't play its role then it will also lose the earning UC that it supposed to earn from the enforcement of laws regarding environmental sustainability, where $(U>1)$. $U$ is the intensity of fine or punishment. 
3. The environmental loss cost for the society is $\mathrm{K}$, if the government fulfills its responsibilities, it can be on the benefit side, and the benefit here is $\mathrm{C}$. These benefits government will receive from the firm for environmental sustainability.

4. The role of civil society can be to monitor the behavior of the government and the firm and play their role accordingly. In a case when civil society doesn't play their role, the environmental benefit is 0 . However, when the government collects fine, the amount will be utilized for the betterment of environment and society. So, in this case the benefit of society is 2UC.

5. The above are the utilities of the government, firm and civil society. It can be stated here that environmental problems are higher in developing countries due to poor legal frameworks. The strong legal system in developed countries ensures that firms confirms with environmental compliance. However, the problem for the firm is to satisfy environmental responsibility that is a dynamic game process because the government has a choice to introduce or not to introduce the green regulation. Whereas, the firm does not have a choice of fulfilling environmental responsibility and non-compliance with environmental responsibility because when the government introduce the mechanism to sustain the environment, then firm have to follow if firm don't follow the government regulations, the firm will face fine imposed by the government. However, civil society has a choice to influence or not to influence the green mechanism for environmental sustainability. So, the game process is a significant theoretical tool to achieve the balance situation.

According to the aforesaid assumptions and payoffs, this study develops a model based on a dynamic game theory among the government, the firm and civil society using the dynamic game of complete information. The dynamic game involves the cooperative game between the government, firm and civil society. The specific dynamic game model is as follows:

\section{Behavior of Participants and their Subsequent Probability}

1. The Government: Introduce green regulations, the probability is ( $\mathrm{r}$ ) and No- green regulation, the probability is $(1-r)$.

2. Firm: Fulfill its environmental responsibility the probability is (p) and do not fulfill environmental responsibility $(1-\mathrm{p})$.

3. Civil Society: if play role for environment sustainability, the probability is (q) and not to play role, the probability is $(1-q)$.

In order to derive the utility function of each participant, the study used the game tree model to analyze it (Figure 1). Based upon the dynamic game among the government, firm and civil society, a game tree for environmental sustainability is shown in Figure 1.

Using the game tree (Figure 1), the study also used game matrix analysis of the parties to determine the utility matrix as shown in the table 1 , from (I) to (VIII) below.

The functions (I) to (VIII) are the utility matrix of all participants. The first part is the utility of the government; the second is firm utility functions and third is the utility functions of civil society.

After the establishment of a game tree and payoff matrix, it is necessary to solve the dynamic game to reach equilibrium solution. Since the order of the game stage is government - firm- civil society, however, it is necessary to solve the payoff solution of the firm first due to its importance in all process. The optimal solution of the government and civil society are also being obtained. Finally, the optimal solution of all three participants is the equilibrium solution of the dynamic game model. 
Figure 1. Game tree based on dynamic game of complete information

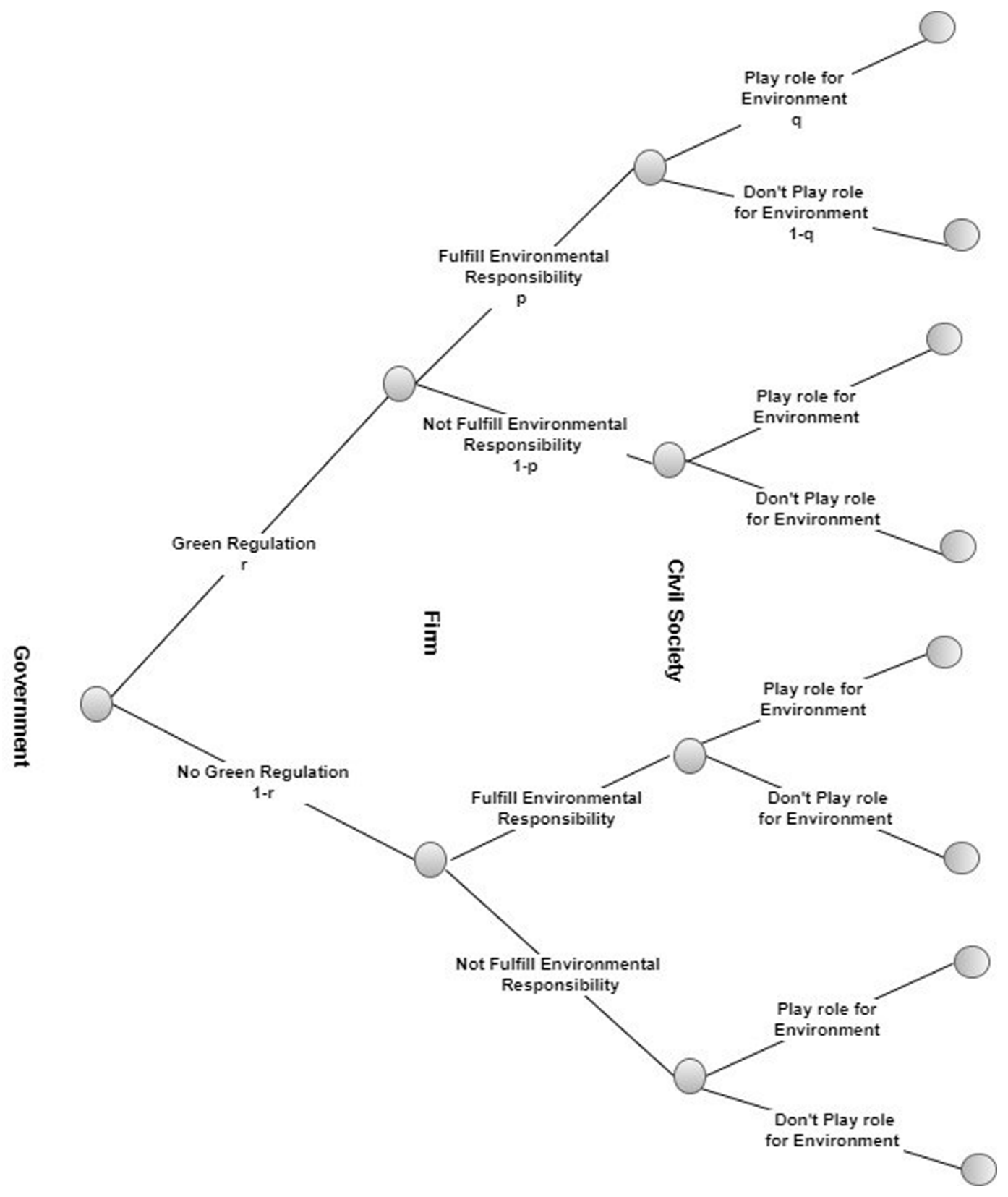

\section{Equilibrium Analysis}

The equilibrium solution of the dynamic game can be solved by the game tree and the income matrix. The equilibrium solution is being analyzed as follows:

1. The Expected Return/Utility Function of the Firm 
Table 1. Payoff matrix

\begin{tabular}{|c|c|c|c|}
\hline & Government & Business & Society \\
\hline I. & $E C$ & $(1-E) C$ & $-C$ \\
\hline II. & $-M C$ & $-U(1-E) C$ & $U C-K$ \\
\hline III. & $-U C$ & $-C$ & $U C-K$ \\
\hline IV. & $C$ & $-C$ & $-K$ \\
\hline V. & $-U(1+E) C$ & $-U(1-E) C$ & $2 U C-K$ \\
\hline VI. & $C$ & $-C$ & $-2 C$ \\
\hline VII. & $(1+E) C$ & $(1-E) C$ & 0 \\
\hline VIII. & 0 & $-\mathrm{C}$ & \\
\hline
\end{tabular}

Based upon the payoff matrix, behavior of the participants and probability, the expected payoff equation for the firm can be written the as follows:

\section{Equation 1}

$$
\begin{aligned}
\text { Firm } & =(1-q)(1-r)(1-p)(1-E) C-q(1-r)(1-p) U(1-E) C \\
& -p q r C-q(1-r) p C-q r(1-p) U(1-E) C-(1-q) r p C \\
& +(1-q) r(1-p)(1-E) C-(1-q)(1-r) p C
\end{aligned}
$$

The above (equation 1) is an expected utility function of the firm which can be simplified based upon the dynamic game theory of complete information to get the optimal value from the function. As the dynamic game theory suggests that partial derivative of the function can be calculated to get the optimal value from the function. Let compute the partial derivative and let them be equal to 0 :

\section{Equation 2}

$$
\begin{aligned}
& \quad \frac{\partial \text { Firm }}{\partial p}=-(1-q)(1-r)(1-E) C+q(1-r) U(1-E) \\
& \text { Let }-q r C-q(1-r) C-q r U(1-E) C-(1-q) r C \\
& +(1-q) r(1-E) C-(1-q)(1-r) C=0
\end{aligned}
$$

Equation 2 is simplified and we get the value as follows in the form of equation 3: 


\section{Equation 3}

$q=\frac{1}{(U+1) C}$

\section{The Government's Expectations}

Based upon the payoff matrix, behavior of the participants and probability, the expected payoff equation for the government can be written the as follows:

\section{Equation 4}

$$
\begin{aligned}
\text { Government } & =-q(1-r)(1-p) M C-p q r U C+q(1-r) p C \\
& -q r(1-p) U(1+E) C+(1-q) r p C \\
& +(1-q) r(1-p)(1+E) C+(1-q)(1-r)(1-p) E C
\end{aligned}
$$

The expected payoff function of the government can be solved by taking partial derivatives to get the optimal value from the function. Let compute the partial derivative and let them be equal to 0 :

\section{Equation 5}

$$
\begin{aligned}
& \frac{\partial \text { Government }}{\partial r}=-p q+q(1-p) M C-p q U C \\
\text { Let } & -q(1-p) U(1+E) C+(1-q) p C \\
& +(1-q)(1-p)(1+E) C-(1-q)(1-p) E C=0
\end{aligned}
$$

Equation 5 is simplified and we get the value as follows in the form of equation 6 :

\section{Equation 6}

$$
\mathrm{p}=\frac{1}{\mathrm{C}}
$$

\section{The Expected Payoff for the Civil Society}

Based upon the payoff matrix, behavior of the participants and probability, the expected payoff equation for civil society can be written the as follows:

\section{Equation 7}

Civil Society $=q(1-r)(1-p)(U C-K)+q r p(U C-K)-q(1-r) p K+q p(1-p)(2 U C-K)-(1-q) r p C-2(1-q) r(1-p) C-(1-q)(1-r)(1-p) C$ 
The expected payoff function of the civil society can be solved by taking partial derivatives to get the optimal value from the function. Let compute the partial derivative and let them be equal to 0 :

\section{Equation 8}

$$
\begin{aligned}
& \frac{\partial \text { civil society }}{\partial q}=r p(U C-K)-(1-q) p K+r(1-p)(2 U C-K) \\
\text { Let } & +(1-q)(1-p)(U C-K) \\
& +r p C-2 r(1-p) C+(1-r)(1-p) C=0
\end{aligned}
$$

Equation 8 is simplified and we get the value as follows in the form of equation 9:

\section{Equation 9}

$\mathrm{r}=\frac{\mathrm{K}}{\mathrm{U}+1}$

Based on the subsequent analysis, authors have accomplished the maximum expected utility/returns of the civil society, the government and firm. Hence, based on the dynamic equilibrium solutions of the firm, the government and civil society, it can be drawn three propositions.

\section{Proposition 1}

From equation $3, q=\frac{1}{(U+1) C}$, it can be inferred that the intensity of punishment, $\mathrm{U}$, business satisfies the environmental responsibility by paying the cost of $\mathrm{C}$ and the probability of civil society to play their role (q) is inversely proportional, When $\mathrm{C}, \mathrm{U}$ is smaller, the probability q is larger, which reflects that smaller the punishment, greater the role of civil society for environmental sustainability.

\section{Proposition 2}

The results from equation 6 indicate that $\mathrm{r}=\frac{\mathrm{K}}{\mathrm{U}+1}$ which means higher the level of punishment, the higher the probability of government intervention, which enhance the role of the government for environmental sustainability. But, it also reflects that the appropriate increase in penalties reduces the role of government intervention. It means, when environmental cost for society is higher, and then the role of the government is also higher for the implementation of environmental responsibility and punishment.

\section{Proposition 3}

The optimal point equation $9 \mathrm{p}=\frac{1}{\mathrm{C}}$ shows that if the cost of environmental responsibility is low, the probability of firm to fulfill the environmental responsibility is higher. In real life, the high cost of environmental responsibility is the main reason that the firm does not fulfill the environmental responsibility. Under the high cost, the firm often has the phenomenon of bribery to the government other means to avoid the environmental responsibility. 


\section{DISCUSSION}

Based upon the subsequent analysis, this paper argues that to promote the environmental responsibility, policy maker worldwide should design and enforce green regulations. However, for the enforcement of green regulations, governments should engage civil society and increase their role for supervision. The coordination with the civil society and giving them right to monitor the environmental responsibility of the government and firm is proposed in the context of developing countries. Because in the context of developed countries; the enforcements of laws are already strong, which ensures that firm follow the environmental regulations. As discussion from the subsequent part has highlighted that the government and firm are the main participants that are creating worse conditions for the environment. However, due to poverty and low level of education in developing countries, the common public is unaware and can't be influential for environmental sustainability. Thus, the role of civil society should be strengthened to cope with environmental issues in these countries. Moreover, the distribution of environmental responsibility cost should be reasonable. The above analysis has indicated that the probability of the firm to fulfill their environmental responsibility depends upon the environmental cost. In real life, the high cost of environmental responsibility is the main reason that the firm does not fulfill the environmental responsibility. Under the high cost, the firm often has the phenomenon of bribery to government officials and use other means to avoid the environmental responsibility in the context of developing countries. The government collects taxes from a common man and also from the factories in developed and developing countries. Therefore, the governments in developing countries should compensate firms similar to developed countries, so that firms can bear environmental responsibility happily and don't try to find unacceptable ways to avoid environmental responsibility.

As the government regulates and control the environmental system in the country, so its role is the most crucial for environmental sustainability. So, it is the responsibility of the government to play the role for environmental sustainability. The governments in developing countries should not only introduce green regulations, but it should also facilitate the firms like firms are facilitated in developed countries. Furthermore, it can be seen that if the firm has the realization of environmental responsibility, the pressure of social supervision will be smaller; the supervision cost is also low. Thus, from the perspective of strengthening environmental responsibility, the important means can be to promote environmental responsibility, such as the governments in developing countries can emphasize on publicity and education related to environmental responsibility. Moreover, the governments in developing countries can encourage firms to play their role for energy saving and reduction in carbon emissions. Further, in order to stimulate the enthusiasm of firms to fulfill their environmental responsibilities, the government can make firms realize that environmental responsibility helps to improve their corporate reputation. It is conducive to long-term sustainable competitiveness of firms to upgrade, so it can also reduce the supervision of the government and civil society efforts. When the firm realizes to fulfill its environmental responsibility, it will be the win-win situation for all players.

\section{CONCLUSION AND POLICY IMPLICATIONS}

The decision-making process seeks consensus among scholars and practitioners in providing an outline/ mechanism to cope with global environmental issues. Policy makers worldwide prefer the mechanisms that provide quick and reliable roadmap for policy formulation. However, there is also a consensus that there is no mechanism available that can help in policy formulation to cope with environmental issues in the context of developing countries. Therefore, this study has been designed to put forward a game theory-based mechanism that outlines the role of the government, firm and civil society to ensure the environmental sustainability for future generations. In this study, we used a dynamic game theory of complete information to understand the equilibrium solutions for the government, firm and civil society to provide the basis for policy makers to understand how and when the government, firm and civil society must intervene and play a vital role for environmental 
sustainability. Based upon the equilibrium analysis, the study has highlighted that when the punishment for non-compliance with environmental responsibility is smaller, the role of civil society would be higher for environmental sustainability. On the other hand, when the environmental responsibility cost is higher, then the role of the government is also higher for the implementation of environmental responsibility and to ensure the punishment. However, we found from model analysis that if the cost is low, the probability of firm to fulfill environmental responsibility is higher. In real life, the high cost of environmental responsibility is the main reason that the firm does not fulfill environmental responsibility. Under the high cost, the firm often has the phenomenon of bribery to government institutions and other means to avoid environmental responsibility.

The study provides valuable suggestions for policy makers worldwide. Based upon the equilibrium analysis and scientific literature, this study has highlighted that there is a poor framework of legislation for environmental issues in the context of developing countries as compare to developed countries. Therefore, the first implication from this study is that policy makers worldwide should emphasize on introducing green regulations to cope with environmental issues and also the government should ensure the implementation of green regulations. Moreover, the government should strictly penalize the firms those are not following the green regulations. For this purpose, the government can also engage the civil society to ensure the implementation of green regulation. But, the government must include the role of civil society in green regulations; otherwise it would not be easy to engage civil society for the purpose of environmental sustainability.

In case of developing countries worldwide, only few industries have their own recycling plants to recycle the wastage of their factories. For example, in the context of Pakistan, a developing country, the government should take strict actions to their emissions and wastage according to the NEQS under the 1997 Act to sustain the environment for future generations. If any industry violates the rules of the country and create harmful conditions for the environment, should be punished with heavy fine. In addition, creating public awareness through education can also improve environmental conditions in worldwide. 


\section{REFERENCES}

Abid, M., \& Ashfaq, A. (2015). CPEC: Challenges and opportunities for Pakistan. Journal of Pakistan Vision, 16(2), 142-169.

Abid, M., Schilling, J., Scheffran, J., \& Zulfiqar, F. (2016). Climate change vulnerability, adaptation and risk perceptions at farm level in Punjab, Pakistan. The Science of the Total Environment, 547, 447-460. doi:10.1016/j. scitotenv.2015.11.125 PMID:26836405

Ahmed, K., Shahbaz, M., Qasim, A., \& Long, W. (2015). The linkages between deforestation, energy and growth for environmental degradation in Pakistan. Ecological Indicators, 49, 95-103. doi:10.1016/j.ecolind.2014.09.040

Ali, M., \& Athar, M. (2008). Air pollution due to traffic, air quality monitoring along three sections of National Highway N-5, Pakistan. Environmental Monitoring and Assessment, 136(1), 219-226. PMID:17385053

Anwar, J. (2016). Analysis of energy security, environmental emission and fuel import costs under energy import reduction targets: A case of Pakistan. Renewable \& Sustainable Energy Reviews, 65, 1065-1078. doi:10.1016/j. rser.2016.07.037

Azam, M., \& Khan, A. Q. (2016). Urbanization and environmental degradation: Evidence from four SAARC countries-Bangladesh, India, Pakistan, and Sri Lanka. Environmental Progress \& Sustainable Energy, 35(3), 823-832. doi:10.1002/ep.12282

Azizullah, A., Khattak, M. N. K., Richter, P., \& Häder, D.-P. (2011). Water pollution in Pakistan and its impact on public health—a review. Environment International, 37(2), 479-497. doi:10.1016/j.envint.2010.10.007 PMID:21087795

Bajari, P., Hong, H., \& Ryan, S. P. (2010). Identification and estimation of a discrete game of complete information. Econometrica, 78(5), 1529-1568. doi:10.3982/ECTA5434

Bernauer, T., \& Gampfer, R. (2013). Effects of civil society involvement on popular legitimacy of global environmental governance. Global Environmental Change, 23(2), 439-449. doi:10.1016/j.gloenvcha.2013.01.001

Bernauer, T., Gampfer, R., Meng, T., \& Su, Y.-S. (2016). Could more civil society involvement increase public support for climate policy-making? Evidence from a survey experiment in China. Global Environmental Change, 40,1-12. doi:10.1016/j.gloenvcha.2016.06.001

Betsill, M. M., \& Corell, E. (2008). NGO diplomacy: the influence of nongovernmental organizations in international environmental negotiations. Mit Press.

Cheffins, B. R. (1997). Company law: theory, structure, and operation. Oxford, MA: Clarendon Press.

CIA. (n.d.). The World Factbook - Central Intelligence Agency Retrieved August 03, 2017, from https://www. cia.gov/library/publications/the-world-factbook/geos/pk.html

Colman, A. M. (2013). Game theory and its applications: In the social and biological sciences. Psychology Press.

Coutinho, M., \& Butt, H. K. (2014). Environmental Impact Assessment Guidance for Coal Fired Power Plants in Pakistan. National Impact Assessment Programme, IUCN Pakistan.

Daud, M., Nafees, M., Ali, S., Rizwan, M., Bajwa, R. A., Shakoor, M. B., \& Murad, W. et al. (2017). Drinking Water Quality Status and Contamination in Pakistan. BioMed Research International. PMID:28884130

Drews, S., \& Van den Bergh, J. C. (2016). What explains public support for climate policies? A review of empirical and experimental studies. Climate Policy, 16(7), 855-876. doi:10.1080/14693062.2015.1058240

Edenhofer, O., Steckel, J. C., Jakob, M., \& Bertram, C. (2018). Reports of coal's terminal decline may be exaggerated. Environmental Research Letters, 13(2), 024019. doi:10.1088/1748-9326/aaa3a2

Epstein, M. J., \& Buhovac, A. R. (2014). Making sustainability work: Best practices in managing and measuring corporate social, environmental, and economic impacts. Berrett-Koehler Publishers.

Farooqui, S. Z. (2014). Prospects of renewables penetration in the energy mix of Pakistan. Renewable \& Sustainable Energy Reviews, 29, 693-700. doi:10.1016/j.rser.2013.08.083 
Fiedler, P. E. K., \& Zannin, P. H. T. (2015). Evaluation of noise pollution in urban traffic hubs-Noise maps and measurements. Environmental Impact Assessment Review, 51, 1-9. doi:10.1016/j.eiar.2014.09.014

Finch, K. C., Snook, K. R., Duke, C. H., Fu, K.-W., Tse, Z. T. H., Adhikari, A., \& Fung, I. C.-H. (2016). Public health implications of social media use during natural disasters, environmental disasters, and other environmental concerns. Natural Hazards, 83(1), 729-760. doi:10.1007/s11069-016-2327-8

Gao, Y., Li, Z., Wang, F., Wang, F., Tan, R. R., Bi, J., \& Jia, X. (2018). A game theory approach for corporate environmental risk mitigation. Resources, Conservation and Recycling, 130, 240-247. doi:10.1016/j. resconrec.2017.12.009

Grigorescu, A. (2007). Transparency of intergovernmental organizations: The roles of member states, international bureaucracies and nongovernmental organizations. International Studies Quarterly, 51(3), 625-648. doi:10.1111/ j.1468-2478.2007.00467.x

Harijan, K., Uqaili, M. A., Memon, M., \& Mirza, U. K. (2011). Forecasting the diffusion of wind power in Pakistan. Energy, 36(10), 6068-6073. doi:10.1016/j.energy.2011.08.009

Khalil, H. B., \& Zaidi, S. J. H. (2014). Energy crisis and potential of solar energy in Pakistan. Renewable \& Sustainable Energy Reviews, 31, 194-201. doi:10.1016/j.rser.2013.11.023

Khan, M. A., Khan, J. A., Ali, Z., Ahmad, I., \& Ahmad, M. N. (2016). The challenge of climate change and policy response in Pakistan. Environmental Earth Sciences, 75(5), 412. doi:10.1007/s12665-015-5127-7

Li, S., \& Xu, J. (2018). Game analysis among the central government, local governments, and firms in China's environmental pollution governance. Paper presented at the IOP Conference Series: Earth and Environmental Science. doi:10.1088/1755-1315/153/6/062007

March, R. G. (2016). Detection of Forest Mortality from the 2011 Texas Drought and Examination of Environmental Drivers.

McVea, H., \& Charalambu, N. (2014). Game theory and sovereign wealth funds. Journal of Financial Regulation and Compliance, 22(1), 61-76. doi:10.1108/JFRC-12-2012-0049

Mehdi, M. R., Kim, M., Seong, J. C., \& Arsalan, M. H. (2011). Spatio-temporal patterns of road traffic noise pollution in Karachi, Pakistan. Environment International, 37(1), 97-104. doi:10.1016/j.envint.2010.08.003 PMID:20851468

Myerson, R. B. (2013). Game theory. Harvard university press.

Önder, S., \& Akay, A. (2015). Reduction of Traffic Noise Pollution Effects by Using Vegetation, Turkey'Sample. Journal of Engineering and Economic Development, 2(2), 23.

Osborne, M. J., \& Rubinstein, A. (1994). A course in game theory. MIT press.

Poudel, H. N. (2016). State of Human Development: SAARC and Nepal. Economic Literature, 12, 50-55. doi:10.3126/el.v12i0.14887

Poundstone, W. (1993). Prisoner's Dilemma/John von Neumann, Game Theory and the Puzzle of the Bomb. Anchor.

Qudrat-Ullah, H. (2015). Independent power (or pollution) producers? Electricity reforms and IPPs in Pakistan. Energy, 83, 240-251. doi:10.1016/j.energy.2015.02.018

Qudrat-Ullah, H., \& Karakul, M. (2007). Modelling for policy assessment in the electricity supply sector of Pakistan. International Journal of Energy Sector Management, 1(3), 240-256. doi:10.1108/17506220710821125

Qureshi, S. (2010). The fast growing megacity Karachi as a frontier of environmental challenges: Urbanization and contemporary urbanism issues. Journal of Geography and Regional Planning, 3(11), 306.

Rasmusen, E., \& Blackwell, B. (1994). Games and information. Cambridge, MA: Blackwell.

Roseland, M. (2000). Sustainable community development: Integrating environmental, economic, and social objectives. Progress in Planning, 54(2), 73-132. doi:10.1016/S0305-9006(00)00003-9 
Rosenbloom, S. (2001). Sustainability and automobility among the elderly: An international assessment. Transportation, 28(4), 375-408. doi:10.1023/A:1011802707259

Sassi, P. (2016). Built Environment Sustainability and Quality of Life (BESQoL) Assessment Methodology. In Engaging stakeholders in education for sustainable development at university level (pp. 21-32). Cham, Switzerland: Springer.

Schelling, T. C. (2010). Game theory: A practitioner's approach. Economics and Philosophy, 26(1), 27-46. doi:10.1017/S0266267110000040

Severo, E. A., de Guimarães, J. C. F., \& Dorion, E. C. H. (2017). Cleaner production and environmental management as sustainable product innovation antecedents: A survey in Brazilian industries. Journal of Cleaner Production, 142, 87-97. doi:10.1016/j.jclepro.2016.06.090

Severo, E. A., de Guimarães, J. C. F., Dorion, E. C. H., \& Nodari, C. H. (2015). Cleaner production, environmental sustainability and organizational performance: An empirical study in the Brazilian Metal-Mechanic industry. Journal of Cleaner Production, 96, 118-125. doi:10.1016/j.jclepro.2014.06.027

Severo, E. A., \& Guimarães, J. C. F. D. (2015). Corporate environmentalism: An empirical study in Brazil. International Journal of Business and Globalisation, 15(1), 81-95. doi:10.1504/IJBG.2015.070225

Sheikh, M. A. (2009). Renewable energy resource potential in Pakistan. Renewable \& Sustainable Energy Reviews, 13(9), 2696-2702. doi:10.1016/j.rser.2009.06.029

Shi, G.-M., Wang, J.-N., Fu, F., \& Xue, W.-B. (2017). A study on transboundary air pollution based on a game theory model: Cases of SO2 emission reductions in the cities of Changsha, Zhuzhou and Xiangtan in China. Atmospheric Pollution Research, 8(2), 244-252. doi:10.1016/j.apr.2016.09.003

Tariq, M. I., Afzal, S., Hussain, I., \& Sultana, N. (2007). Pesticides exposure in Pakistan: A review. Environment International, 33(8), 1107-1122. doi:10.1016/j.envint.2007.07.012 PMID:17765971

Valasai, G. D., Uqaili, M. A., Memon, H. R., Samoo, S. R., Mirjat, N. H., \& Harijan, K. (2017). Overcoming electricity crisis in Pakistan: A review of sustainable electricity options. Renewable \& Sustainable Energy Reviews, 72, 734-745. doi:10.1016/j.rser.2017.01.097

Van Rooy, A. (2004). The global legitimacy game: Civil society, globalization and protest. Springer. doi:10.1057/9780230000957

Wakeel, M., Chen, B., \& Jahangir, S. (2016). Overview of energy portfolio in Pakistan. Energy Procedia, 88, 71-75. doi:10.1016/j.egypro.2016.06.024

Waseem, A., Arshad, J., Iqbal, F., Sajjad, A., Mehmood, Z., \& Murtaza, G. (2014). Pollution status of Pakistan: A retrospective review on heavy metal contamination of water, soil, and vegetables. BioMed Research International. PMID:25276818

Wolters, H., \& Schuller, F. (1997). Explaining supplier-buyer partnerships: A dynamic game theory approach. European Journal of Purchasing \& Supply Management, 3(3), 155-164. doi:10.1016/S0969-7012(97)00011-7

Yamin, F. (2001). NGOs and international environmental law: A critical evaluation of their roles and responsibilities. Review of European, Comparative \& International Environmental Law (Northwestern School of Law), 10(2), 149-162.

Zaman, K., Abdullah, A., Khan, A., Nasir, M. R. M., Hamzah, T. A. A. T., \& Hussain, S. (2016). Dynamic linkages among energy consumption, environment, health and wealth in BRICS countries: Green growth key to sustainable development. Renewable \& Sustainable Energy Reviews, 56, 1263-1271. doi:10.1016/j.rser.2015.12.010

Zaman, K., Abdullah, I., \& Ali, M. (2017). Decomposing the linkages between energy consumption, air pollution, climate change, and natural resource depletion in Pakistan. Environmental Progress \& Sustainable Energy, 36(2), 638-648. doi:10.1002/ep.12519

Zameer, H., \& Wang, Y. (2018). Energy production system optimization: Evidence from Pakistan. Renewable \& Sustainable Energy Reviews, 82, 886-893. doi:10.1016/j.rser.2017.09.089

Zameer, H., Wang, Y., Yasmeen, H., Mofrad, A. A., \& Saeed, R. (2018). A game-theoretic strategic mechanism to control brand counterfeiting. Marketing Intelligence \& Planning, 36(5), 585-600. doi:10.1108/MIP-02-2018-0053 
Zhang, R., Andam, F., \& Shi, G. (2017). Environmental and social risk evaluation of overseas investment under the China-Pakistan Economic Corridor. Environmental Monitoring and Assessment, 189(6), 253. doi:10.1007/ s10661-017-5967-6 PMID:28477273

Zürn, M. (2004). Global governance and legitimacy problems. Government and Opposition, 39(2), 260-287. doi:10.1111/j.1477-7053.2004.00123.x

Humaira Yasmeen is an Associate Professor at the college of Economics and Management, Nanjing University of Aeronautics and Astronautics, Nanjing, China.

Ying Wang, Professor of College of Economics and Management, Nanjing University of Aeronautics and Astronautics, Nanjing 211106, China. Main research area: industrial economics and management, international finance and investment, global value chain and sustainable development

Hashim Zameer is a PhD candidate in the College of Economics and Management, Nanjing University of Aeronautics and Astronautics, Jiangsu, Nanjing, China. He has more than 6 years of teaching and research experience. His research interests lie in Services Marketing, Consumer Behavior and Brand Management. His work has appeared in internationally recognized journals including the International Journal of Bank Marketing, Human Systems Management, Pakistan Journal of Sandro Bimonte is a researcher at Irstea, and more exactly he is at TSCF. He received his PhD from INSA-Lyon, France (2004-2007). From 2007-2008, he carried out researches at IMAG, France. He is an editorial board member of the International Journal of Decision Support System Technology and the International Journal of Data Mining, Modelling and Management, and a member of the Commission on GeoVisualisation of the International Cartographic Association. His research activities concern spatial data warehouses and spatial OLAP, visual languages, geographic information systems, spatiotemporal databases, and geo-visualisation. and International Journal of Customer Relationship Marketing and Management. 